KOŚCIÓŁ I PRAWO 9(22) 2020, nr 2, s. 125-138

DOI: http://dx.doi.org/10.18290/kip2092-9

Tomasz Słapczyński

\title{
POJĘCIE DOBRA JAKO WYZNACZNIK WARTOŚCIOWANIA PRZEPISÓW PRAWA POWSZECHNEGO
}

\section{POJĘCIE DOBRA I JEGO PODZIAŁ DOKTRYNALNO-SYSTEMOWY W PRAWIE}

Państwo demokratyczne musi kierować się obiektywnymi wartościami wyrażanymi przez ogół społeczeństwa. W modelu państwa świeckiego zazwyczaj panuje porządek stanowiący o równouprawnieniu wszystkich Kościołów (wyznań) w granicach danego państwa, zaś państwo samo w sobie powinno utrzymywać porządek społeczny, gwarantować wolność i niezależność [Romanko 2018b, 128]. Jest to wynik dobra, jakim jest równość i poszanowanie innych. Skupiając się jednak na wiarze katolickiej i prawach przysługujących wiernym w Kościele katolickim należy podkreślić, że im także przysługuje dochodzenie i obrona przysługujących w Kościele uprawnień na właściwym forum kościelnym według przepisów prawa [Taż 2018a, 368]. Jest to ważne z punktu widzenia ochrony ich dóbr w strukturze Kościoła katolickiego. Tak samo władza kościelna - ustanawiając zasady czy też sprawując zarząd - powinna starać się, aby realizować najważniejszy cel, jakim jest dobro indywidualne wiernego, ale także dbać o dobro publiczne i wspólne. Każda władza powinna być sprawowana dla dobra innych [Wroceński 2018, 227]. Prawa wiernych Kościoła katolickiego oparte

Mgr TOMASz SŁAPCZYŃSKI, DOKTORANT - Wydział Politologii i Dziennikarstwa, Uniwersytet Marii Curie-Skłodowskiej w Lublinie; e-mail: tslapczynski@gmail.com; https:// orcid.org/0000-0002-9636-1673 
są na wartościach dobra [Krukowski 1996, 227-28]. Ponadto należy zauważyć, że Kościół katolicki nieustannie naucza, iż obrona godności osoby ludzkiej i praw człowieka powinna mieć fundament w trwałych wartościach ludzkich, istniejących obiektywnie niezależnie od zmiennych opinii subiektywnych [Tenże 2010, 401]. Bezkompromisowe dążenie do odkrywania prawdy oraz wdrażanie zasad prawa, dobra i słuszności w społeczności Kościoła i państwa polskiego jest wartością najważniejszą [Wroceński 2010, 21]. Należy także poszukiwać wartości leżących u podstaw prawa i moralności, które Kościół wypracował zwłaszcza w odniesieniu do współczesnej kultury [Krukowski 2010, 400]. Jak zauważa M. Sitarz - za Janem Pawłem II - w dzisiejszych czasach, bardziej niż kiedykolwiek, potrzeba ludzi uczciwych i tylko ludzie dobrze ukształtowani, z głęboko zakorzenionymi normami i wartościami, mogą odpowiedzialnie pełnić powierzone im funkcje i właściwie kierować losami Ojczyzny [Sitarz 2016, 73]. Jednak w ujęciu historycznym, nie zawsze w stanowieniu prawa kierowano się pojęciem i wartością dobra, gdyż wartościami nadrzędnymi, np. w okresie powojennym do 1989 r., było dobro partii i państwa socjalistycznego [Tenże 2020, 377].

Pojęcie dobra w ujęciu klasycznym należy wiązać z filozofią, począwszy od myślicieli starożytności poprzez wieki średnie. Ujęcie klasyczne charakteryzowało się silnymi związkami z etyką, jako normatywną wiedzą o dobru w ludzkim postępowaniu. Podejście aksjologiczne daje możliwość oceny słuszności konkretnego zdarzenia oraz ewentualnie jego klasyfikacji. Ustrojodawca w preambule Konstytucji $\mathrm{RP}^{1}$ eksponuje uniwersalne wartości uznawane przez państwa demokratyczne, takie jak prawda, sprawiedliwość, dobro czy piękno. Podkreśla także potrzebę udzielania ochrony takim dobrom, jak: wolność, równość wobec prawa, niezbywalna i przyrodzona godność człowieka. Dobro jest pojęciem wywodzącym się z filozofii. Posiada ono podłoże czysto aksjologiczne. To co dla jednych jest dobrem, czymś wartościowym, dla innych może nie być wartością równie doniosłą. Dobro indywidualne jest odbierane zawsze bardzo subiektywnie, inaczej niż dobro wspólne czy dobro grupowe, które to musi wziąć pod uwagę uśrednione, optymalne czynniki tak, aby jego wartość była jak najbardziej

\footnotetext{
${ }^{1}$ Konstytucja Rzeczypospolitej Polskiej z dnia 2 kwietnia 1997 r., Dz. U. z 2009 r., $\mathrm{Nr} 114$, poz. 946.
} 
satysfakcjonująca dla jak najliczniejszej grupy podmiotów z tego dobra korzystających.

Państwo polskie stanowiące prawo mające na celu dobro wspólne wszystkich obywateli (narodu w znaczeniu politycznym) może i powinno zgodnie z Konstytucją RP - realizować niektóre zadania na rzecz jego esencjalnej części, tj. Polaków (narodu polskiego w znaczeniu etnicznym), o ile te zadania nie stoją $\mathrm{w}$ drastycznej sprzeczności $\mathrm{z}$ jego podstawową charakterystyką „państwa obywatelskiego” [Garlicki 2010, 91].

\subsection{Dobro względne i bezwzględne}

W nauce prawa karnego można wyróżnić dobra o względnej oraz bezwzględnej wartości dla społeczeństwa. Dobra względne podlegają ochronie jedynie na wniosek dysponenta dobra, natomiast dobra bezwzględne podlegają ochronie niezależnie od jego woli. Dobra o bezwzględnej wartości dla społeczeństwa, zwane są także dobrami obiektywnymi czy dobrami o obiektywnej wartości społecznej.

Zgodnie z poglądem K. Buchały i A. Zolla wszystkie przypadki, w których ochronie podlega tylko dobro o względnej wartości społecznej, podlegają ochronie za zgodą dzierżyciela dobra. Zgoda na jego zagrożenie lub zniszczenie powoduje, że przestaje ono mieć wartość społeczną i nie podlega ochronie. Dobro o bezwzględnej wartości dla społeczeństwa, zwane również „dobrem obiektywnym lub o obiektywnej wartości społecznej”, charakteryzuje się tym, że jego ochrona jest niezależna od decyzji jego posiadacza. Wartość tego dobra nie ma charakteru dyspozycyjnego. Przykładem takiego dobra jest życie, nie może być w ono związku z tym dobrem względnym [Tarapata 2016].

\subsection{Dobra ogólne i szczególne}

Innym sposobem klasyfikowania dóbr jest ich podział na dobra ogólne i dobra szczególne. Dobra ogólne są właściwe każdemu przestępstwu, z racji jego przynależności do zbioru przestępstw. Są one charakterystyczne dla godzenia $\mathrm{w}$ stosunki odpowiadające interesom społecznym. Jednak z punktu widzenia prawa karnego sama możliwość wyodrębnienia ogólnego dobra chronionego prawem jest obecnie kwestionowana: „W Polsce Ludowej wyróżniano w doktrynie prawa karnego tzw. ogólny przedmiot ochrony, przez który nawiązując do klasowego charakteru prawa karnego rozumiano całokształt stosunków społecznych, w utrzymaniu których 
zainteresowana była klasa panująca. Jednakże wyróżnienie ogólnego dobra chronionego nie wydaje się ani możliwe, ani celowe, ponieważ trudno jest wskazać ogólną wartość, która byłaby chroniona przez wszystkie przepisy prawa karnego" [Grześkowiak 2007, 78].

Ochrona dóbr ogólnych stanowi generalny przedmiot ochrony przepisów prawa karnego [Gubiński 1996, 49]. Natomiast dobra szczególne to zamknięty katalog dóbr, które są penalizowane konkretnie w ustawie, „z nazwy”. Przykładem dobra ogólnego może być dobro prawne w postaci porządku publicznego. Jest to konieczność przestrzegania porządku prawnego.

\subsection{Dobro grupowe}

Innym pojęciem, korespondującym w pewnym zakresie z dobrem wspólnym jest dobro grupowe. Jest to przedmiot ochrony, który jest wspólny dla pewnej grupy przepisów. Inaczej rzecz ujmując, jest to indywidualne dobro mieszczące się w ramach grupowego przedmiotu ochrony [Śliwowski 1979, 70]. Podział ten wydaje się być logicznie uzasadniony, jeśli będzie odnosił się nie do konkretnych przepisów, ale do pewnych grup norm posiadających wspólne cechy [Tarapata 2016].

\subsection{Dobro rodzajowe}

W doktrynie prawa karnego wyróżnia się także tzw. dobro rodzajowe, rodzajowy przedmiot ochrony. Stanowi on łącze pomiędzy dobrem chronionym ogólnym, a dobrem chronionym szczególnym. Dobro rodzajowe jest bardziej konkretne i szczegółowe od dobra ogólnego. Jest także bardziej ogólne od dobra bezpośredniego. Może być stopniowane co do jego konkretyzacji, przesuwając poziom jego szczegółowości od dobra ogólnego do dobra bezpośredniego. Rodzajowym przedmiotem ochrony może być dobro prawne jednostki. Będzie ono wspólne dla szerokiej gamy przepisów. Można wyróżnić takie rodzajowe przedmioty ochrony, jak życie, wolność, nietykalność osobistą, dobre imię, dobra osobiste. Jednak jednorodzajowość na gruncie ustawy Kodeks karny skarbowy ${ }^{2}$ jest rozumiana trochę inaczej. Zgodnie $\mathrm{z}$ art. $53 \S 12$, przestępstwa skarbowe tego samego rodzaju to te, które są określone w tym samym rozdziale kodeksu. Np. przestępstwa skarbowe z użyciem przemocy lub groźby jej użycia, są klasyfikowane jako

\footnotetext{
${ }^{2}$ Ustawa z dnia 10 września 1999 r. Kodeks karny skarbowy, Dz. U. z 2020 r., poz. 19 z późn. zm.
} 
przestępstwa skarbowe tego samego rodzaju [Kardas, Łabuda, i Razowski 2012, 507].

\subsection{Dobro główne i uboczne}

Ponadto w doktrynie można odnaleźć także podział dóbr na dobra główne oraz dobra uboczne (pośrednie, dodatkowe) [Bojarski 2008, 107]. Dokonując tego podziału należy uwzględnić, co w typie czynu zabronionego stanowi dobro główne, a co można uznać za uboczne dobro prawne (które zostało naruszone dodatkowo, a też ma być chronione). Należy rozstrzygnąć to abstrakcyjnie, według rozdziału kodeksu, w którym dany przepis się znajduje. W konkretnej sytuacji rzecz może się przedstawiać odmiennie, dobro główne może ponieść mniejszy uszczerbek niż uboczne. Podział ten, który jest szeroko komentowany w literaturze, został poddany krytyce przez A. Marka oraz W. Świdę [Marek 2011, 111]. Drugi ze wskazanych autorów podkreślił: „Niekiedy w doktrynie te bezpośrednie przedmioty ochrony, które są uwzględniane przez ustawodawcę przy grupowaniu przestępstw według przedmiotów ochrony, są nazwane «bezpośrednimi», «głównymi» w przeciwstawieniu do "pośrednich», «ubocznych» czy «dodatkowych», nie wziętych pod uwagę przy klasyfikacji. Wydaje się, że taka nomenklatura jest myląca, gdyż może sugerować, że ten «pośredni», «dodatkowy», «uboczny» przedmiot ochrony jest mniejszej wagi niż ten, który jest nazywany «głównym» czy «bezpośrednim»". Należy także znaczyć że A. Marek, przedstawił podział dóbr prawnie chronionych na dobra bliższe i dobra dalsze. Dobra dalsze czy dodatkowe nie są mniej ważne z punktu widzenia przepisów prawa i podlegają takiej samej ochronie, jedyną różnicą jest rola, jaką dane dobro odgrywa w klasyfikacji rodzajowej przestępstw [tamże].

\subsection{Dobra materialne, niematerialne, indywidualne i zbiorowe}

Zarówno w prawie cywilnym, administracyjnym, jak i karnym, wyróżnia się dobra materialne (fizyczne) i dobra niematerialne. Podział ten ma jednak sens przy przyjęciu pewnego założenia. Można mówić o pewnych wartościach, które mogą przybierać postać materialną lub niematerialną [Tarapata 2016]. Do przykładów postaci materialnej można zaliczyć życie lub zdrowie, do przykładów dóbr niematerialnych pokój czy porządek publiczny. 
Innym istotnym rozróżnieniem jest podział na dobra indywidualne i dobra ogólne (generalne lub zbiorowe). Dobro indywidualne może być przypisane do konkretnego podmiotu, np. dobro osobiste, życie, zdrowie.

Podziały te są pewną abstrakcją przyjętą przez doktrynę, za pomocą której można stwierdzić, czy dana wartość może być materializowana lub indywidualizowana poprzez odpowiednie jej sklasyfikowanie.

\subsection{Dobra osobiste}

Przepisy prawa zarówno karnego, jak i cywilnego (a także innych gałęzi) zapewniają ochronę dobrom osobistym. W judykaturze pojawiają się poglądy, że na gruncie art. 12 Kodeksu karnego ${ }^{3}$ chodzi nie tyle o dobra osobiste (jak w Kodeksie cywilnym ${ }^{4}$ ), ile o dobra ściśle osobiste, takie jak życie, zdrowie, wolność, cześć, nietykalność osobista ${ }^{5}$. Jednak zgodnie z poglądami doktryny, należy przyjąć, że przepis ten odnosi się szeroko do każdego dobra osobistego [Królikowski i Zawłocki 2017, 503]. Za dobra osobiste $\mathrm{w}$ prawie cywilnym należy uznać wartości niematerialne łączące się ściśle $\mathrm{z}$ jednostką ludzką [Dmowski i Rudnicki 2009, 106]. Z kolei art. 23 k.c., określa otwarty katalog wartości wyszczególniając jedynie przykłady dóbr mogących podlegać ochronie.

\subsection{Dobro publiczne i prywatne}

Ponadto doniosłym podziałem na gruncie prawa jest podział na dobra publiczne i dobra prywatne. W tej kwestii ważnym przepisem jest art. 231 $\S 1$ k.k., zgodnie z którym „funkcjonariusz publiczny, który, przekraczając swoje uprawnienia lub nie dopełniając obowiązków, działa na szkodę interesu publicznego lub prywatnego, podlega karze pozbawienia wolności do lat 3". W tym wypadku katalog podmiotów ochrony będzie co do zasady tożsamy z podziałem na dobra indywidualne i dobra ogólne [Tarapata

\footnotetext{
${ }^{3}$ Ustawa z dnia 6 czerwca 1997 r. Kodeks karny, Dz. U. z 2020 r., poz. 1444 z późn. zm. [dalej cyt.: k.k.].

${ }^{4}$ Ustawa z dnia 23 kwietnia 1964 r. Kodeks cywilny, Dz. U. z 2020 r., poz. 1740 z późn. zm. [dalej cyt.: k.c.].

${ }^{5}$ Wyrok Sądu Apelacyjnego w Warszawie z dnia 29 stycznia 2003 r., sygn. akt II AKa 510/02, Lex nr 80599; wyrok Sądu Apelacyjnego w Lublinie z dnia 19 kwietnia 2004 r., sygn. akt II AKa 75/04, http://www.lublin.sa.gov.pl/20,48,wyrok-z-dnia-19kwietnia-2004-roku-ii-aka-7504-prok-i-pr-200411-1230.htm [dostęp: 09.07.2020]; wyrok Sądu Apelacyjnego w Krakowie z dnia 9 czerwca 2004 r., sygn. akt II AKa 111/04, Lex nr 138073.
} 
2016]. Podział dóbr na dobra publiczne i prywatne jest także istotny z punktu widzenia prawa publicznego, $\mathrm{w}$ tym prawa administracyjnego, finansowego, itp. Pomaga on określić sam obszar działania objętego prawem publicznym. Jednak na kanwie prawa publicznego ważna jest zarówno ochrona interesu wspólnego, jak i interesu indywidualnego. Jak podkreśla M. Wyrzykowski zmienność terminu „interes publiczny (społeczny)” uzależniony jest od epoki, gałęzi prawa oraz konkretnej regulacji ustawowej prawa administracyjnego [Wyrzykowski 1986, 11]. W języku prawnym i prawniczym w 20-leciu międzywojennym przeważało pojęcie interesu publicznego. Odnoszone było głównie do społeczeństwa i władzy oraz do ich wzajemnej relacji. Zgodnie z uzasadnieniem do wyroku (sygn. akt II K 285/33， OSN(K) 1933/8/157) „Interesem jest bądź istniejące bądź przyszłe dobro materialne lub osobiste, lub dobro idealne, związane $\mathrm{z}$ organizacją życia zbiorowego i prawidłowością jej funkcjonowania. Publicznym natomiast jest interes zbiorowy organizacji społecznej, państwa lub samorządu, albo w ogóle życia społecznego".

\section{DOBRO WSPÓLNE JAKO DOBRO UNIWERSALNE}

Zgodnie z art. 1 Konstytucji RP „Rzeczpospolita Polska jest dobrem wspólnym wszystkich obywateli”. Sama kolejność przytaczanego przepisu, dobro wspólne $\mathrm{w}$ porównaniu z frazą wspólne dobro, stanowi określoną wartość niematerialną, która świadczy o wadze i wymowie tego dobra. Dobro wspólne jest wartością, która była analizowana już w starożytności. Począwszy od Arystotelesa, poprzez analizy dokonywane przez św. Tomasza z Akwinu, do czasów nowożytnych i współczesnych, jako istotny element społecznej nauki Kościoła katolickiego, w tym rozważań papieża Jana Pawła II i jego następców.

W kulturze europejskiej pojawiły się dwie doniosłe koncepcje dobra, z którego później wywiedziono ideę dobra wspólnego: emanacyjna (platońsko-plotyńska) oraz finalistyczna (arystotelesowska). Odpowiednio do tych koncepcji dobra, ukształtowały się dwa modele społeczne: tzw. mechaniczny, gdzie społeczeństwo uważane jest za bezładne skupisko ludzi, hordę. Drugi, organiczny - gdzie społeczeństwo postrzegane jest jako zbiór osób powiązanych wzajemnymi relacjami. Koncepcja dobra oraz koncepcja społeczności wiążą się nierozerwalnie $\mathrm{z}$ pojęciem dobra wspólnego jako dobra 
wszystkich członków społeczności. Ponadto, zgodnie z platońską koncepcją dobra, istnieje tzw. dobro emanacyjne, zgodnie z którym do natury dobra należy jego udzielanie się na zewnątrz, jego wylewność [Krąpiec 2001, 1-2]. Dobro może być też postrzegane jako motyw działania, zgodnie z poglądem Arystotelesa. „Wszelka sztuka i wszelkie badanie, a podobnie też wszelkie zarówno działanie, jak i postanowienie, zdają się zdążać do jakiegoś dobra" [Arystoteles 1956].

Z kolei tomistyczne ujęcie dobra wspólnego jest podstawą jego dwudziestowiecznej koncepcji, która została implementowana do nauk prawnych. Św. Tomasz z Akwinu wyróżniał dwie koncepcje dobra wspólnego (bonum commune). Pierwsza, było to dobro wspólne utożsamiane $\mathrm{z}$ dobrem całego wszechświata oraz jego ład (bonum totius universi). To na jego podstawie każdy człowiek i cała ludzkość uczestniczy w Bożym dziele, który jest najwyższym dobrem.

Druga koncepcja określa dobro wspólne jako dobro społeczności ludzkich (dobro wspólne w znaczeniu właściwym i ścisłym). Jest ono elementem składowym każdej społeczności. Najdoskonalszą oraz naturalną formą organizacji społeczeństwa jest państwo, które wywodzi się ze społecznej natury człowieka. Natomiast celem państwa i prawa w nim obowiązującego jest zapewnienie dobra powszechnego (wspólnego). Działanie każdego człowieka ma charakter rozumny, dlatego musi być ono skierowane na osiągnięcie dobra całej społeczności. Św. Tomasz z Akwinu określa dobro wspólne jako cel stanowiący motyw działania każdego przez człowieka. Podstawą działania na rzecz dobra wspólnego jest zrozumienie i świadome uznanie go jako działania na rzecz swojego dobra. Wolna natura jednostki wymaga samodzielnego zauważania wartości i charakteru dobra wspólnego, rolą społeczeństwa jest kształtowanie człowieka, aby przyjął on działanie na rzecz dobra wspólnego, jako coś dobrego także dla niego samego [Zamelski 2012, 180-205].

\subsection{Geneza pojęcia dobra wspólnego}

Należy zauważyć, iż dobro wspólne posiada pozaprawną genezę zaczerpniętą z filozofii i etyki. Definiując państwo św. Augustyn uwzględniał konkretne zagadnienia, stanowiące najważniejsze elementy struktury społecznej. Podkreślał kwestię wagi niezmienności obowiązujących zasad, kładł także nacisk na ideę dobra wspólnego, sprawiedliwości i uczciwości władzy. Dobrze funkcjonujące państwo widział jako takie, w którym prze- 
strzega się zasady dobra wspólnego, co oznacza uznanie przez wszystkich obywateli posiadania wspólnego interesu, który byłby ważniejszy od osobistych korzyści. Taka postawa zdaniem św. Augustyna wymaga poświęcenia pewnych dóbr osobistych w celu ratowania lub powiększenia dobra wspólnego, co może przyczynić się do wymiernych korzyści dla całej społeczności. Tam, gdzie dobro wspólne nie jest przestrzegane, państwo słabnie, nie chroni dostatecznie swoich obywateli i ich dóbr osobistych, co może spowodować rozpad całego państwa. Innym ważnym czynnikiem, postrzeganym przez św. Augustyna, sprzyjającym rozwojowi państwa i poczuciu bezpieczeństwa wśród obywateli, jest przestrzeganie zasady sprawiedliwości społecznej [Sienkiewicz 2015, 209-10].

Istota dobra wspólnego stała się częścią prospołecznie ukierunkowanych doktryn polityczno-prawnych, znajdując się w przepisach prawa pozytywnego, zyskała status zasady prawnej. Zgodnie z poglądem M. Granata, rzadko korzysta się z klauzuli art. 1 Konstytucji w ocenie badanych aktów normatywnych. Ponadto trudno dać odpowiedź, co jest istotą i treścią dobra wspólnego. „Jest ono wartością pierwotną, a nie którą konfrontujemy z innymi wartościami [...] W takim posługiwaniu się dobrem wspólnym nie ma chyba stałego mechanizmu [...] trybunał [...] odsłania zarazem na czym polega dobro wspólne w sytuacji konkretnej kolizji zasad i wartości” [Winczorek 2014, 209].

F. Longchamps de Berier analizując poczynania rzymskiego pretora doszedł do wniosków w kwestiach interpretowania dobra wspólnego, że „z subiektywnej perspektywy obywateli, danego momentu dziejów, rożny bywa ogół warunków, jakie pozwalają na integralny rozwój jednostek, jak i całej społeczności. W tym sensie dobro wspólne podlega historycznej relatywizacji, co nie podważa sensowności samej kategorii dobra wspólnego ani prób wskazywania, kto i w jaki sposób przyczynia się do jego realizacji”. Zgodnie z art. 126, art. 154-155 oraz art. 173-174 Konstytucji RP organy państwa powinny działać na rzecz ochrony i tworzenia dobra wspólnego, dobra które posiada wielką niematerialną wartość dla całego narodu [tamże].

\subsection{Historia zagadnienia dobra wspólnego $\mathrm{w}$ prawie polskim}

Zagadnienie dobra wspólnego rozważane i procedowane było w pracach nad projektem Konstytucji RP, w Zgromadzeniu Narodowym w latach 1995-1997. Druga forma, wspólne dobro, jest bliższa raczej Konstytucji 
obowiązującej w Polsce od 1935 r., w której postanowiono w art. 10: „Państwo polskie jest wspólnym dobrem wszystkich obywateli”. Zgodnie z Konstytucją z 1935 r. wspólnym dobrem było państwo, w zależności od interpretacji, rozumiane jako aparat władzy publicznej lub wspólnota obywatelska. Wtedy to obowiązki obywateli wobec państwa wysuwały się na pierwszy plan, a ich prawa i wolności pełniły rolę drugoplanową. Ponadto art. 7 ust. 1 Konstytucji z 1935 r., stanowił, że „wartością wysiłku i zasług obywatela na rzecz dobra powszechnego mierzone będą jego uprawnienia do wpływania na sprawy publiczne". Co traktowało dobro wspólne nie jako dobro niematerialne przysługujące obywatelom, lecz jako przywilej i obowiązek do pracy na rzecz wspólnoty. Dobro wspólne w Konstytucji RP jest „pojmowane jako suma społecznych warunków integralnego rozwoju wszystkich członków, wspólnoty politycznej, a przyrodzona i niezbywalna godność jest z punktu widzenia prawa pierwszą współokreślającą warunki rozwoju jednostek; warunki te dookreślane są wolnościami i prawami człowieka i obywatela, których źródłem jest godność" [Piechowiak 2012, 21720]. Przychylając się do klasycznej formuły dobra wspólnego niekoniecznie należy odrzucać „nieklasyczną formułę”, w której dobrem wspólnym obywateli jest państwo. Ponadto Konstytucja RP wprowadza zasadę, iż państwo polskie nie może być państwem jednego tylko narodu, lecz dobrem wszystkich, którzy je zamieszkują. Zgoła inaczej było w Konstytucja PRL z 1952 r., gdzie państwo miało charakter klasowy [tamże].

\subsection{Dobro wspólne w prawie publicznym}

Należy zaznaczyć że prawo publiczne, które faktycznie chroni wartości dobra wspólnego, zawiera normy ingerujące w sferę wolności obywatelskich, ze względu na ochronę interesu publicznego (dobra wspólnego) chronionego przez organy administracji publicznej. W zakresie prawa administracyjnego obydwa te aspekty związane $\mathrm{z}$ wolnością nieustannie się przeplatają. Ustawodawca, a w ślad za nim organy stosujące prawo administracyjne, powinny zawsze wyważać interesy stojące wobec siebie w konflikcie i szczególnie przy tym, dbać o ochronę wolności obywatelskich. Wolności człowieka i obywatela w demokratycznym państwie prawnym stanowią wartości najważniejsze i należy je chronić wszelkimi sposobami [Zimmermann 2017, 1-3].

Właściwym przykładem ochrony dobra wspólnego jest chociażby zagadnienie środowiska naturalnego. Pojęcie dobra wspólnego nabiera w tym 
wypadku szczególnego znaczenia w perspektywie malejącej ilości zasobów naturalnych, uprawiania tzw. gospodarki rabunkowej czy zanieczyszczania środowiska. Konstytucja RP pośrednio reguluje kwestie ochrony środowiska w art. 5, chociażby poprzez wprowadzenie zasady zrównoważonego rozwoju stanowiącej, iż Rzeczpospolita Polska strzeże niepodległości i nienaruszalności swojego terytorium, chroni wolność i prawa człowieka oraz obywatela, strzeże dziedzictwa narodowego i zapewnia ochronę środowiska, kierując się zasadą zrównoważonego rozwoju. Art. 5 Konstytucji RP jest przepisem o charakterze programowym, co oznacza, iż jest to ogólna idea, która powinna być realizowana poprzez zarówno organy sprawujące władze, jak i administrację publiczną [Garlicki 2007, 2].

\section{ZAKOŃCZENIE}

W artykule podjęto próbę syntetycznego przedstawienia znaczenia pojęcia dobra w polskim porządku prawnym oraz wartości, na których pojęcie dobra jest oparte, w tym wartościach wyprawowanych przez filozofię klasyczną czy też nauczanie Kościoła katolickiego. Pojęcie dobra jest ważne z punktu widzenia wartości wyznawanych przez społeczeństwo jako całość, ale także i poszczególne grupy społeczne. W czasach socjalistycznych pojęcie dobra było wypaczane na potrzeby polityczne. W czasach obecnych, w ustroju demokratycznym, także nie brakuje kontrowersji z wartościowaniem dobra, jednak jest to specyfika tego pojęcia, należącego do sfery aksjologii. Co ważne właściwe definiowanie dobra służy prawidłowemu prawodawstwu, ale także właściwemu stosowaniu prawa. Pojęcie to skłania podmioty stosujące prawo do czynienia tego co dobre i słuszne. Najważniejszymi cechami prawa już od czasów starożytnych były bowiem zasady dobra i słuszności (bonum et aequum). Inne ważne zasady oparte na starożytnych wartościach to: iustitia (sprawiedliwość), humanitas (człowieczeństwo, życzliwość), aequitas (słuszność, równość), fides (wiara, zaufanie), honestas (uczciwość, rzetelność) i wiele innych, łączących prawo z etyką [Kuryłowicz 2001, 9-11]. Prawo, zgodnie z rzymskimi wartościami, było sztuką stosowania tego, co dobre i słuszne (ius est ars boni et aequi) oraz sprawiedliwe (iustitia). Było to odzwierciedlenie woli przyznawania każdemu należnego mu prawa [Kupiszewski 1988, 176-79]. Jednak należy pamiętać, że te fundamentalne kanony, aby służyły społeczeństwu, muszą 
być właściwie interpretowane. Wypracowane przez przedstawicieli nauki podziały dóbr są próbą teoretycznej ich klasyfikacji. Dobra nie mogą opierać się jedynie na przepisach prawa i wywodach doktrynalnych, wtedy mamy do czynienia z pozytywizmem i normatywizmem, które to czasami stawiają wolę ustawodawcy ponad dobro. Najważniejszy jest nie podział dóbr, lecz każdorazowa ocena podejmowanych działań, tak aby czyniono dobro akceptowane społecznie.

\section{PIŚMIENNICTWO}

Arystoteles. 1956. Etyka nikomachejska. Tłum. Daniela Gromska. Warszawa: PWN.

Bojarski, Tadeusz. 2008. Polskie prawo karne. Zarys części ogólnej. Warszawa: LexisNexis.

Dmowski, Stanisław, i Seweryn Rudnicki. 2009. Komentarz do kodeksu cywilnego. Księga pierwsza. Część ogólna. Warszawa: LexisNexis.

Garlicki, Leszek, red. 2007. Konstytucja Rzeczypospolitej Polskiej. Komentarz. T. 5. Warszawa: Wydawnictwo Sejmowe.

Grześkowiak, Alicja, red. 2007. Prawo karne. Warszawa: Wydawnictwo C.H. Beck.

Gubiński, Arnold. 1996. Zasady prawa karnego. Warszawa: PWN.

Krąpiec, Mieczysław A. 2001. „Dobro wspólne.” W Powszechna Encyklopedia Filozofii, red. Andrzej Maryniarczyk. Lublin: Polskie Towarzystwo Tomasza z Akwinu. http://www.ptta.pl/pef/ pdf/d/dobrow.pdf [dostęp: 25.02.2020].

Królikowski, Michał, i Robert Zawłocki, red. 2017. Kodeks karny. Część ogólna. Komentarz. Warszawa: Wydawnictwo C.H. Beck.

Krukowski, Józef. 1996. „Prawa wiernych do dobrej opinii i do własnej intymności. Komentarz do kan. 220 KPK z 1983 r.” Prawo Kanoniczne 39, nr 3-4:227-36.

Krukowski, Józef. 2010. „Rec.: Kard. Zenon Grocholewski, Refleksje na temat prawa prawo naturalne, filozofia prawa, Wydawnictwo Homo Dei, Kraków 2009, ss. 101.” Prawo Kanoniczne 53, nr 1-2:399-401.

Kupiszewski, Henryk. 1988. Prawo Rzymskie a wspótczesność. Warszawa: PWN.

Kuryłowicz, Marek. 2001. „Prawo rzymskie jako fundament europejskiej kultury prawnej." Zeszyty Prawnicze 1:9-25.

Kardas, Piotr, Grzegorz Łabuda, i Tomasz Razowski, red. 2012. Kodeks karny skarbowy. Komentarz. Warszawa: Wolters Kluwer Polska.

Marek, Andrzej. 2011. Prawo karne. Warszawa: Wydawnictwo C.H. Beck.

Piechowiak, Marek. 2012. Dobro wspólne jako fundament polskiego porzadku konstytucyjnego. Warszawa: Biuro Trybunału Konstytucyjnego.

Romanko, Agnieszka. 2018a. „Prawo do obrony w kanonicznym procesie karno-administracyjnym. Zarys problematyki." Teka Komisji Prawniczej PAN Oddział w Lublinie XI, nr 2:363-73.

Romanko, Agnieszka. 2018b. „System państw świeckich na przykładzie wybranych państw europejskich.” Biuletyn Stowarzyszenia Absolwentów i Przyjaciót Wydziału Prawa Katolickiego Uniwersytetu Lubelskiego XIII, nr 15 (1):127-41.

Sienkiewicz, Edward. 2015. „Koncepcja państwa według św. Augustyna.” Studia Paradyskie, t. 25, 201-20. 
Sitarz, Mirosław. 2016. „10 lat istnienia Stowarzyszenia Absolwentów i Przyjaciół Wydziału Prawa Katolickiego Uniwersytetu Lubelskiego.” Biuletyn Stowarzyszenia Absolwentów i Przyjaciót Wydziału Prawa Katolickiego Uniwersytetu Lubelskiego XI, nr 13 (2):73-86.

Sitarz, Mirosław. 2020. „Wpływ sytuacji politycznej na wolność religijną w Polsce w latach 1918-1989." Teka Komisji Prawniczej PAN Oddział w Lublinie XIII, nr 1:377-87.

Śliwowski, Jerzy. 1979. Prawo karne. Warszawa: PWN.

Tarapata, Szymon. 2016. Dobro prawne $w$ strukturze przestepstwa. Analiza teoretyczna i dogmatyczna. https://sip.lex.pl/\#/monograph/369397092/26 [dostęp: 25.11.2020].

Winczorek, Piotr. 2014. „Rec.: W. Arndt (red.), ks. F. Longchamps de Bérier, K. Szczucki, Dobro wspólne. Teoria i praktyka, Warszawa 2013.” Przegląd Sejmowy 3:209-13.

Wroceński, Józef. 2010. „Prezentacja Księgi Pamiątkowej dedykowanej Ks. prof. dr hab. Remigiuszowi Sobańskiemu z okazji osiemdziesiątej rocznicy urodzin.” Prawo Kanoniczne 53, nr 3-4: 21-23.

Wroceński, Józef. 2018. „Aspekt prawny posługi przełożonego zakonnego i jego odpowiedzialność w prowadzeniu wspólnoty.” Sympozjum XXII, nr 2(35):223-48.

Wyrzykowski, Mirosław. 1986. Pojęcie interesu społecznego $w$ prawie administracyjnym. Warszawa: Wydawnictwo Uniwersytetu Warszawskiego.

Zamelski, Piotr. 2012. „Wybrane koncepcje dobra wspólnego w ujęciu prawnonaturalnym i normatywnym.” W Efektywność europejskiego systemu ochrony praw człowieka. Ewolucja i uwarunkowania europejskiego systemu ochrony praw człowieka. Część I: Współczesne rozumienie praw człowieka, red. Jerzy Jaskiernia, 180-205. Warszawa: Wydawnictwo Adam Marszałek.

Zimmermann, Jan, red. 2017. Wolność $w$ prawie administracyjnym. Warszawa: Wolters Kluwer Polska.

\section{Pojęcie dobra jako wyznacznik wartościowania przepisów prawa powszechnego}

\section{Streszczenie}

Jest rzeczą właściwie oczywistą, iż prawo realizuje wartości społecznie doniosłe. Opiera się ono na wartościach filozoficznych Europy, w tym wartościach chrześcijańskich. Artykuł analizuje pojęcie dobra i wartości nim wytyczanych wypracowanych w doktrynie prawa i prawa kanonicznego. Należy podkreślić, iż przyjęto wartościującą klasyfikację „dobra”, właściwą dla subiektywizmu aksjologicznego. Nie wyklucza to jednak możliwości ujęcia tego samego „dobra” w sposób obiektywny, zgodnie z zasadami filozofii klasycznej, jednak klasyczne ujęcie dobra jest i było już przedmiotem wielu bardzo istotnych opracowań.

Artykuł podejmuje próbę klasyfikacji doktrynalnej oraz omówienie istoty pojęcia dobra jako wartości aksjologicznej dla polskiego porządku prawnego - wartości mającej wpływ na kształtowanie i stosowanie prawa.

Słowa kluczowe: dobro; dobro w ujęciu Kościoła katolickiego; aksjologia prawa; wartości w prawie; doktryna prawa 


\section{The Concept of Good as a Significant Value in Law Rules}

\section{Summary}

It is in fact obvious that the law implements socially significant values. It is based on the philosophical values of Europe, including Christian values. The paper is focusing on the concept of good and the values it sets out in the doctrine of law and canon law. It should be emphasized that a evaluative classification of "good" was adopted, appropriate for axiological subjectivism. However, this does not exclude the possibility of presenting the same "good" objectively, in accordance with the principles of classical philosophy, but the classic approach to good has already been the subject of many very important studies.

The work attempts to classify doctrinal classification and discuss the essence of showing the concept of good for the Polish legal order as a value that has an impact on the formulation and application of law.

Key words: good; good in terms of the Catholic Church; axiology of law; values in law; legal doctrine

Information about Author: TOMASZ SŁAPCZYŃSKI, M.A., PH.D. STUDENT - Faculty of Political Science and Journalism, Maria Curie-Skłodowska University in Lublin; e-mail: tslapczynski@gmail.com; https://orcid.org/0000-0002-9636-1673 